\title{
THE ECONOMIC EMPOWERMENT OF CHILD LABOUR IN FAMILY BUSINESS AT CIBADUYUT FOOTWEAR INDUSTRY
}

\author{
Sumardani $^{1}$ and Yuyun Yuningsih ${ }^{2}$ \\ ${ }^{1,2}$ Social Welfare Department, Universitas Pasundan, Indonesia \\ ${ }^{1}$ sumardani@unpas.ac.id
}

\begin{abstract}
Child labour tend to have high hazards and risks especially when they grind and glue a sole tothe upper part of the shoes. Shoes making remains to be a hazardous work for children and adults as long as chemical-based solvents are used. To overcome these problems, the goverment of the Republic of Indonesia launched a program by giving some aids to the parents of the child laborer to run their small business so that their children can stop working at the shoemaking industry.This research aims at analyzing the economic empowerment of parents who employed their children in the online business industry at Cibaduyutfootwear industry and use a qualitative approach with a triangulation of data collected. The research informants were the child laborer, parents who employed their children, footwear craftsmen, and the Head of Industry and Trade Agency. The results of this research showed that economic empowerment in child laborer'sparents was still in low level and they could not market their shoes properly as a product of their smallbusiness. In this context, they need both training and workshop in social entrepreneurship and online business method in order to promote their product.
\end{abstract}

\section{Keywords: Economic Empowerment, Child Labour, Business Industry}

\section{Introduction}

Nowadays, Cibaduyut footwear industry began to experience a decline in its production and sales because of the imported and diverse footwear products that made the people turn to the imported products. Currently,Cibaduyut footwear industry has 577 business units that must be maintained.

The decreasing annual production is one of the measures in which the marketing strategy carried out by the business owners at Cibaduyut footwear industry hasnot been effective. For this reason, breakthroughs and changes from offline businesses to online businesses must be made by the owners, by becoming sellers in various marketplaces such as Tokopedia, Bukalapak, and so on. The rapid potential use of internet technology through online business or online shop is an opportunity for the development of efforts to empower and increase the technology-based people's economy. Socialization and training related to the empowerment of internet technology through online business is very important, including socialization and education for families in increasing household income so that family welfare increases (Zaen et al., 2017).

According to Internet World States, in 2005, the world internet users reached 972,828,001 (almost one billion), and users in Indonesia were estimated at 16 million people. The largest number of users were from the United States and Canada, which reached $68.2 \%$ of the total population (Syah, 2015). The use of current technology can help people communicate, connect, enhance personal relationships, and bring new business opportunities.

Business Marketing Strategy Through Internet Marketing - Today the internet has become one of the basic needs for humans, especially urban communities throughout the world, including in Indonesia. The number 
of internet users that continues to increase every year becomes a very promising potential for those who want to use it. For business people, the internet is one solution to improve their business performance. Just look, now almost all offline businesses have created websites and created social media accounts for their businesses.

Progress in the world of internet technology turned out to bring great benefits to business people, namely using it in business marketing strategies.

Product marketing through internet media aims at encouraging the development of small craftsmen. Therefore, in order to increase family income for the craftsmen can be developed by utilizing information technology, the support in form of training and provision of facilities are needed. The biggest responsibility for giving training and providing these facilities is in the hands of the government, in addition to other parties who have a commitment.

Through this training activity, it is expected that the business of Cibaduyut footwear industry, which becomes the icon of Bandung, can continue to grow amidst the global market rush. It can be done through selling products online and empowering the families as distributors (Kompas.com).

Research related to this problem was also carried out by Nuryetyet al. (2017). The results of the research explained that the use of information technology in running a business or often known as e-commerce for small companies couldprovide flexibility in production, enabling faster delivery to customers for software products, sending and receiving offers quickly and economically, and support fast paperless transactions.

Other research was conducted by Setawaty et al. (2017).Their research aims at finding out the influence of online marketing strategies on the increase of UMKM profit. The results of the research stated that the online marketing strategy had a positive effect on the increase in UMKM profit.

This research is about family empowerment of child laborers in online business at
Cibaduyut footwear industry. The empowerment from child laborers' parents in online business has become a necessity and gets attention from the relevant government, because alleviating child labor depends on the economic strength of the family, if the family's economy increases, child labor in the Cibaduyut footwear industry can be overcome. Purpose of the research is to analyze the empowerment of child laborers from the parents in online business in the footwear industry in Cibaduyut.

\subsection{Empowerment}

Empowerment is essentially humanity, in the sense of encouraging people to present themselves and their rights. Empowerment, according to Suharto, is a learning process includingplanning and systematic effort that carried out continuously and collectively for individuals in order to use the potential power and abilities contained in individuals and community groups so that they are able to carry out social transportation that is directed to be able to master their life.

Community empowerment that has developed nowadays, as has been defined by Ife (2008) is preparing the community in the form of resources, opportunities, knowledge, and expertise to increase the capacity of the community in determining their future, and participating and influencing life in the community itself.

Suharto (2010) explains that empowerment can be done through three approaches, which are:

1. Micro approach. Empowerment is carried out on individuals through guidance, counseling, and crisis intervention. The main goal is to guide or train individuals in carrying out their daily tasks. This model is often referred to as a task-centered approach.

2. Mezzo approach. Empowerment is carried out on community groups. It is carried out by using a group approach as a medium of intervention. Education, training, and group dynamics are usually used as a strategy to increase awareness, knowledge, skills, and attitudes of the group in 
order to have the ability to solve the problems faced.

3. Macro approach. This approach is often referred to as a large-system strategy, because the target of change is directed at a broad environmental system. Policy formulation, social planning, campaigning, social action, organizing, and community development are some of the strategies in this approach.

Based on the above definition, the concept of empowerment is a concept that must be applied to the footwear craftsmen to increase the expected ability and welfare because of the lack of support from the local government in conducting supervision and guidance for craftsmen, and also the absence of organizations that can accommodate the aspirations of Cibaduyut'sshoe craftsmen that became one of the factors the craftsmen went bankrupt. Therefore, empowerment is an alternative in improving the skills of footwear craftsmen in maximizing their abilities.

\subsection{Online business}

Online business is no longer an obscure term in Indonesia, whether for people that are accustomed to using the internet or not. Online business, which was originally only used for promotional and advertising purposes through web pages, has now turned into a multifunctional business, both as a means of promotion, purchase of goods, sale of goods, and also the sale of other services carried out through an online system.

According to Musselman and Jackson (2017), business is the overall organized activity in the field of commerce and industry in the provision of goods and services to meet the needs of the community and to improve the quality of people's lives. Online can be said that the media can be accessed 24 hours a day, seven days a week, and 365 days a year, and can be accessed anywhere at any time as long as there is an internet access in the area.

Makmur (2018: 4) describes the characteristics of an online business, which are: (1) having a seller, (2) having a provider, (3) transfer method, (4) electronic money, (5) e-mail, (6) chatting, (7) telephone, (8) SMS, (9) internet, and (10) in the form of pictures. Thus, online business can be interpreted as a business that is done online by utilizing technological progress.

In a company, marketing plays an important role to carry out integrated communication which aims at providing information from the company to consumers regarding goods or services. This aims at meeting the needs and desires of consumers or customers. The process of fulfilling these needs and desires, later became known as a marketing concept commonly called 4P, namely Product, Price, Place, and Promotion.

\subsection{Online marketing}

Online marketing is a business that markets its products or services through or using internet media by utilizing the internet that is accessed by all people around the world to share information and communicate, including sharing product information, goods, and services sold.E-marketing is the marketing side of e-commerce, it consists of company's efforts to communicate about, promote, and sell products and services over the internet, Kotler (2004).

Online marketing can also be interpreted as the use of data and electronic applications for planning and implementing concepts, distribution, promotion, and pricing to create exchanges that satisfy individual and organizational goals (Strauss and Frost: 2001). Marketing in this way is an alternative business carried out to market a product or service in the global era.

\subsection{Online marketing strategy}

Marketing includes activities related to sales, advertising, promotion, and pricing. Online marketing strategy is all business carried out to market a product or service through or using online media, namely internet media. Despite changes, marketing cannot escape the three components that always accompany it, namely consumers, competitors, and companies.

These three components are always present in every discussion about marketing. Although sometimes the implementation varies in each business, the purpose of marketing promotion is the same, it is to 
introduce the product widely to the public, with the expectation that the public will be interested in the information shared and end up making a purchaseonline, Sumodiningrat (2009).

\section{Method}

This research employsqualitative method. It is a research method that uses qualitative or descriptive data. Qualitative research is a method for exploring and understanding meaning, which is by a number of individuals or a group of people considered to come from social or humanitarian problems(Creswell, 2014: 4).

This training is expected to be one of the solutions in answering the problem of economic improvement of craftsmen families which has been a chronic problem because there is no solution in overcoming marketing problems. IT training is also directed at utilizing existing resources in the community. Qualitative research is a research that utilizes open interviews to examine and understand the attitudes, views, feelings, and behavior of individuals or groups of people who are the object of research.

2.1 Informant determination techniques The informants in this research were the parties involved in the implementation of family empowerment in Cibaduyut's footwear industry, namely the Technical Implementation Unit (UPT, Unit PelaksanaTeknis) of the Industry and Trade Office in Cibaduyut and the family of the child laborers. The determination of the subject of this research is using purposive method, which is those who become informants are deliberately chosen to be able to provide the necessary information related to the implementation of family empowerment by using online business.

\subsection{Data collection techniques}

Data collection techniques related to social protection of child labor include three methods. First, it is by using participant observation and thesecond and the third is interviews and documentation studies.
2.3 Data processing and analysis techniques

The processing and analyzing data or information in qualitative research must be carried out simultaneously. Throughout the process of data analysis, the researchers index and encode data collected in either social events or phenomena that occur, using as many categories and descriptions as possible.

The determination of the site of this research is in the UPT of the Industry and Trade Office in Cibaduyut area in Bandung, with the consideration that the agency was appointed as the implementer of the provision of skills training for the shoe craftsmen in Cibaduyut.

\section{Result and Discussion}

Family empowerment towards the family of the child laborer in the online business industry should be getting the attention from the government because the use of child laborer depends on the economic strength of the family. If the family's economy increases, then the child laborers in the Cibaduyut footwear industry can be overcome and empowering the family of Cibaduyut footwear craftsmen is an urgent need to be executed because most of the people in Cibaduyut work as craftsmen who make footwear that has worked hereditary and has been known by the world as an icon of Bandung.

Empowerment is carried out by the UPT of the Industry and Trade Office inBandung by providing training and counseling in the form of using IT as a promotional media.

\subsection{Socialization}

The UPT of the Industry and Trade Office inBandung that is located in Cibaduyut held a socialization related to empowering the families of small workshop owners and shop owners in the Cibaduyut footwear center related to the provision of footwear design training, the making of clogs using modern machinery and counseling on marketing by using online marketing strategy. The socialization was carried out using an invitation letter delivered to each of the craftsmen in the BojongloaKidul subdistrict. This empowerment activity is 
carried out to improve the abilities and skills of shoe craftsmen in terms of using IT for marketing purposes. Marketing using IT media is a necessity for businesses, because technological developments can also be used as marketing advice. Cibaduyut footwear craftsmen will leave by consumers if they do not follow developments.

\subsection{Identification}

The identification process was carried out to determine the problems experienced by craftsmen in terms of capital, production, and marketing, within a consideration that Cibaduyut footwear industry had existed for generations and had to be preserved by the Cibaduyut people who mostly made a living in this sector. After identifying the problem, the next process is to scale the needs, which needs must be the priority of implementation. Next, the process was carried out bydetermining the potential possessed by the craftsmen.

The results of the interview with the UPTofficers showed that"after doing the identification process, the most perceived problem by the craftsmen is the marketing problem, because the clogs designing training has been carried out by instructors from Bandung Institute of Technology (ITB, InstitutTeknologi Bandung) and the craftsmen have made footwear models in accordance with the demands of change and trends in society. However, in the last five years, sales turnover has continued to decline because the products compete with foreign products, such as products from China, so that a breakthrough in marketing is needed.

\subsection{Training}

The training is held once a year, with a target of 100 participants every year, both for design training and manufacturing of sandals and shoes based on online marketing. The training is in one-week period, starting at 9 to 15 . The participants were divided into two groups. The first grouptook part in the design and manufacture of clogs training, and the other group participated in online-based marketing training ranging from giving material to practice. Every day, participants are given lunch and money.
According to the results of interviews with UPT officers, the implementation of the target could only be filled by $40 \%$ or around 40 craftsmen, from 577 business units in Cibaduyut who participated in the training. Many reasons were raised by the craftsmen, for example if they took part in the training, the craftsmen could not carry out production activities and they would lose income.

Laily et al. (2017) explain that the use of information technology in running a business or often known as e-commerce for small companies can provide flexibility in production, enabling faster delivery to customers for software products, sending and receiving offers quickly and economically, and supports fast paperless transactions.

The training method is in form of lecture method and direct practice, using a group approach as a medium of intervention. The participants were given knowledge and introduction to features and navigation of smartphone, and the way they were operated. This media intervention is considered suitable in training participants, because it can help instructors to provide assistance, meaning that some participants who are considered able to master can help other participants.

For designing and lathing skills, it is not as difficult as teaching IT, because they generally have worked in this field since childhood, and the UPT Industry and Trade in Cibaduyut has been equipped with a lathe for making modern kelom (footwear sandals) so that they can produce better and tidy kelom, and works faster so it can produce more.

\subsection{Instructor}

The UPT of the Industry and Trade Office inBandung for the footwear industry in Cibaduyut has collaborated with the Bandung Institute of Technology to provide empowerment for Cibaduyut footwear workers, so that the training instructors are experts and have good knowledge in the field of footwear design models in accordance with consumer demands. 


\subsection{Material}

Business Marketing Strategy Through Internet Marketing - Today the internet has become one of the basic needs for humans, especially urban communities throughout the world, including in Indonesia. The number of internet users that continues to increase every year becomes a very promising potential for those who want to use it. For business people, the internet is one solution to improve their business performance. Just look, now almost all offline businesses have created websites and created social media accounts for their businesses. Progress in the world of internet technology turned out to bring great benefits to business people, namely using it in business marketing strategies.

Training materials wereprovided according to the demands, needs, and potential possessed by the craftsmen. Sincemost of the craftsmen mostly only graduated from elementary schools (SD) and there were several craftsmen who went to high school (SMA), the material must be adjusted to their capacity. However, all participants have an average mobile phone and can operate it. The material is more directed at the direct practice of how to sell by using social media, such as Instagram, WhatsApp, Facebook, LINE, and others.

Based on the results of interviews with UPT officers, the obstacles faced in the provision of training materials were the ability of participants that were scattered around in different knowledge and understanding, so that it became a challenge for the instructors to provide materials to the participants.

\subsection{Assistance}

Assistance process were carried out by UPT officers to the workers who had received training to measure the success of the training that had been given. Based on the results of interviews with the UPT officers"Assistance is done to ensure that the results of the training can be applied. Assistance is expected to provide the same understanding among various parties, such as the UPT/instructors with footwear craftsmen so that there will be no gap between them. In carrying out their duties, the facilitators position themselves as planners, mentors, informers, motivators, liaisons, facilitators, and evaluators.

The results of the interview with Mr. Dinor showed that one of the training participants who had done by online marketing, said that $60 \%$ production sales had been done online. This was inseparable from the guidance and training provided by the UPT Cibaduyut. In fact, the participant sends the product directly to the buyer, by taking advantage of the cost ofcourier service in Bandung. If the order is from outside of Bandung, the courier service is using inter package services. According to the participants, the training provided by the UPT was very useful. According to Sumodiningrat (2009), mentoring is an activity that is believed to be able to encourage the empowerment of the poor in an optimal manner.

\subsection{Marketing Access}

Through this online marketing strategy, the coverage becomes wider and unlimited. Consumers can find products wherever they are as long as there is internet to access them. Online marketing can provide more convenience for its customers, including the ease of choosing goods and payments, and customers do not need to go to the store. Customers simply sit at home with the gadget and access the internet to access the desired virtual store. Social media users are known to increase yearly. This is a great opportunity for footwear craftsmen to advertise businesses on social media. Thus the products or services offered are increasingly recognized by many people.

Some of the best social media for business marketing include: 1. Facebook, 2.Twitter, 3. Instagram, 4. YouTube. The challenge in marketing through social media is when building content. Each social media has a different treatment in the presentation of content, and requires sufficient knowledge and skills in managing social media accounts for business.

The interview results from Mr. Dinor stated that a craftsman who has used social media as a promotional toolsaid that marketing methods that use social media are dominated by young people, especially those who already understand using IT and most 
footwear stores in Cibaduyut already market their products using Facebook, WhatsApp, and Instagram as the advertising media.

Bagus and Ati (2013) state that advertising marketing through social networks measured through the EPIC method proved very effective. Meanwhile, according to Swastha (2008), the marketing strategy in a craftsman business is significant because it is a method used to achieve the business objectives of the craftsmen.

\subsection{Technical Guidance}

Technical guidance is an activity that is intended to provide assistance which is usually in the form of guidance and advice to solve technical problems. By following the technical guidance, it is expected that every Cibaduyut footwear craftsman can take advantage of being oriented towards improving the quality of footwear production. In addition to technical guidance related to design, the application of technology for making footwear using automatic machinery that is environmentally friendly, also provided technical guidance related to marketing management using online media. One of the causes of the decline in interest to come to shoe shops in Cibaduyut, because of losing competition with online sellers.

The results of the interview with the head of the UPT Cibaduyut revealed that the implementation of technical guidance was carried out after the training participants received business assistance. It was conducted one day in the form of a work meeting and held at the UPT Cibaduyut office as a follow-up to the family empowerment activities of child laborers in the online business as an effort to increase knowledge and ability to conduct promotional efforts using social media.

By facing the facts of the increasingly high level of competition in the business world, training in human resource development or technical guidance has become a necessity for individuals and institutions.

\subsection{Termination}

The empowerment wascarried out on families of child laborers who have a footwear workshop, especially from home industry craftsmen. Empowerment wasdone by using a group approach as a medium of intervention. The training provision is in the form of introduction to internet media such as transfer methods, electronic money, email, chat, telephone, SMS, internet, and image showcase, which wereused as a strategy to increase awareness, knowledge, skills and attitudes in order to have the ability to promote results production to consumers, has been done through a series of process activities and the results have been applied and utilized by the participants well.

The results of interviews with the family of footwear craftsmen that were given training on online business in the form of transfer methods, electronic money, e-mail, chat, telephone, SMS, internet, and image showcase revealed that the ability and knowledge of using IT as a marketing medium can be applied properly. Evidently, around $60 \%$ of consumers make transactions via online media and the rest are still using offline or physical stores.

State that online marketing strategies have a positive effect on the increase in micro, small, and medium enterprises (UMKM) profit [4]. Thus, family empowerment from child laborer should be given, so that footwear craftsmen have the ability to promote production to consumers, thus impacting the welfare of their families.

\section{Conclusion}

Some offline business owners are moving to online business by becoming a seller in various marketplaces such as Tokopedia, Bukalapak, and so on. Likewise, the business owners in the Cibaduyut footwear industry also made several breakthroughs, by changing the pattern of offline business to online business. Empowerment efforts are carried out by the UPT of the Industry and Trade Office to the craftsmen by providing training related to the use of internet technology tools as a promotional medium. The results of the research concluded that from the socialization stage to the termination stage, the trainees were very enthusiastic and responded to the material and practice very well. It was proven that the participants were able to market their 
products through online media, although they were still done individually, they had not built a network with professional online stores such as Tokopedia, Bukalapak,etc. This is a challenge for sellers and the local government to continue to increase the knowledge and skills of footwear industry sellers in Cibaduyut in the field of digital technology.

Cibaduyut footwear industry should have its own online store, and can accept orders and payments on its own website. Given the existence of this industry that has been known internationally. Ironically, most of the footwear businesses in Cibaduyuthave not had digital technology support that enables them to open online stores that are able to receive e-payment on their own website. Regarding this matter, the UPT of the Industry and Trade Office still has the task of doing work with software providers to jointly focus on supporting the empowerment of the footwear business sector in Cibaduyut.

\section{References}

Adi, I. R. (2003). Pemberdayaan, Pengembangan Masyarakat dan Intervensi Komunitas: Pengantar Pada Pemikiran dan Pendekatan Praktis. Jakarta: Lembaga Penerbit Fakultas Ekonomi UI.

Huraerah, A. (2011). Pengorganisasian dan Pengembangan Masyarakat, Model dan Strategi Pembangunan Berbasis Pemberdayaan. Bandung: Humaniora.

Ife, J. (2008). Community Development: Alternatif Pengembangan Masyarakat di Era Globalisasi. Yogyakarta: Pustaka Pelajar.

Kotler, P. (2004). Manajemen Pemasaran, Edisi Milenium. Jakarta: Prehallindo.

Makmur, R. (2018). Bisnis Online, Mengenal, Memulai, dan Mengelola Bisnis Online Melalui Berbagai Media. Bandung: Informatika Bandung.

Suharto, E. (2005). Membangun Masyarakat, Memberdayakan Rakyat. Bandung: Alfabeta.
Suharto, E. (2008). Pembangunan, Kebijakan Sosial \& Pekerjaan Sosial. Bandung: LSP-STKS Bandung.

Suharto, E. (2010). CSR \& COMDEV: Investasi Kreatif Perusahaan di Era Globalisasi. Bandung: Alfabeta.

Sumodiningrat, G. (2009). Mewujudkan Kesejahteraan Bangsa, Menanggulangi Kemiskinan dengan Prinsip Pemberdayaan Masyarakat. Jakarta: PT Alex Media Komputindo.

5.1 Electronic Source:

ejurnal.stiedharmaputra-

smg.ac.id/index.php/PRO/article/do wnload/263/229by I Setiawati (2017). Accessed on 12/8/2018 at 19.30

https://ekonomi.kompas.com/read/2015/09/2 5/194348026/Lakukan.Pemberdaya an.Ekonomi.dengan.

Pembinaan.Berbasis. Teknologi.

Accessed at 19.30 on $7 / 8 / 18$

https://www.jurnal.id/id/blog/2017/4-

strategi-promosi-marketing-untuk-bisnisonline-anda

https://ekonomi.kompas.com/read/2 015/09/25/194348026/Lakukan.Pe mberdayaan.Ekonomi. dengan.Pembinaan.Berbasis.Teknol og.

https://ahliakuntansi.blogspot.com/2018/03/ Pengertian-Bisnis-Online.html 